\title{
Sykes, Jim. 2018. The Musical Gift: Sonic Generosity in Post- War Sri Lanka. Oxford: Oxford University Press.
}

\section{Reviewed by Davindar Singh}

Jim Sykes' The Musical Gift braids several ambitious projects togethersomewhere around seven, depending on how you count it—resulting a book of massive scope for its 250-odd pages. It not only contains histories of the musics of many of Sri Lanka's seemingly religiously and culturally bounded communities, but also a localized history of the politics of identity that formed these boundaries. It contains sweeping histories of musical life "between" the communities that are obscured by this politics of identity. It grounds these histories in Sykes's ethnographic study of Sinhalese Buddhist drummers' attempts to situate their practice within and beyond discourses of identity. The book also contains ethnographic research on the place of sound, music, and musicians in Sri Lanka's recent genocidal conflicts, which Sykes sees as the bloody effects of these politics of identity. It contains Sykes's prescribed response to the conflicts: attention to the historical practices of circulating music and sound between entities marked by social difference, and the perception of these sonic circulations as acts of care and ongoing relationality, which Sykes calls "musical giving." In making the case for "musical giving" as politics, Sykes's monograph mounts a sweeping critique of aesthetic perception shaped by political liberalism and the commodity-form, which Sykes dubs the "music and identity episteme": a reinscription of artificial social division through the relentless search for the community-indexing authenticity of musical expression. This critique tackles many of the fundamental assumptions of music scholarship past and present, in the process entwining two strains of thought that are usually considered politically opposed ("late structuralist" anthropology (Turner 2009) and contemporary political economy). Thus, Sykes's study makes for valuable reading material—not just for region specialists, nor just for students and nonspecialists in music disciplines, but for scholars across disciplines interested in attempts to reconcile both conflict and conflicting forms of political critique.

The book's massive scope and ambition are not without clear influences, and it is in particularly close dialogue with contemporary music scholarship that turns to questions of human and nonhuman agency. Ana Maria Ochoa Gautier's 2014 tour-de-force Aurality looms large, and Sykes draws deeply from the same 


\section{Current Musicology}

conceptual well. In both Aurality and The Musical Gift, contemporary forms of social distinction are seen as arising from distinctions between nature and culture that took shape in the colonial project, with the production of naturalized ethnic difference in postcoloniality taking shape according to colonial logics. In both books, the subsequent role of the scholar is to untangle the working of these logics and entangle the previously-divided "nature" and "culture" produced by them (Sykes 2018, 58-60). This entails recourse to the various contemporary forms of relativizing structuralist anthropology currently dubbed the "ontological turn" (12-13), which is then sutured to a body of thought that ties the problems of ontology to the problems of national politics. In Ochoa Gautier's case this body of thought is primarily the examination of political theology, but in Sykes's case it's a heterodox mixture of critical geography (including a wholly unique conception of music's commoditization (208) directly based on David Harvey's reading of Das Kapital) and actor-network theory (also present in Aurality, but for different purposes).

Though Ochoa Gautier and Sykes are among the few ethnomusicologists to take on anthropology's "ontological turn" (but see Brabec de Mori and Seeger 2013 for precedent, and recent publications such as Dirksen 2020 and Schuiling 2020, which imply that this is a rising ethnomusicological trend), the invocation of actor-network theory brings Sykes and Ochoa in conversation with many other ethnomusicologists (Gavin Steingo, Elliot Bates, Jason Stanyek), and a throng of musicologists (Georgina Born, Benjamin Piekut, and perhaps Tia DeNora and Antoine Hennion). Sykes draws widely and unexpectedly, but is placeable within his peers' concerns (see also Sykes 2020, which ties contemporary "ontological" anthropology and many of The Musical Gift's arguments to the burgeoning conceptual frame of Anthropocenic crisis, increasingly common across social-scientific, musical, and popular publications alike).

The Musical Gift contains six chapters bookended by an introduction and conclusion. These are interspersed with ethnographic interludes meant to unsettle the ostensible fixity of Sri Lanka's ethnic and communal boundaries. The chapters and interludes are in turn grouped into four sections: "Finding Musical Gifts," outlining the basic conceptual premises behind Sykes's conception of "musical giving"; "Musical Giving as Protection and Destruction," tracing the respective and related histories of the musics and sonic rituals of Sri Lanka's Tamil, Sinhalese, Burgher, and Muslim communities; "The Discursive Erasure of Musical Giving," outlining how the interrelation of these histories has been continuously erased in the course of postcolonial genocide; and 
"Rediscovering Musical Giving," examining projects of post-genocidal reconciliation and offers Sykes's own reconciliatory prescriptions.

The introduction makes the case for liberal political thought, and its construction of an individual self within a naturalized group identity, as both the cause of political division and the cause of faults in musical scholarship that analytically centers identity. Sykes dubs the effect of this liberal notion of selfhood on music scholarship - the assumption that music necessarily reflects (or constructs) a naturalized identity demarcated through social boundary formation-the "music and identity episteme (6)." Instead of this "episteme," he proposes that music history turn to non-hierarchical notions of relationality, arguing for attention to non-Western ontologies that "flatten" divisions between human, animal, and divinity in order to remove hierarchy from methodology (67). Sykes posits Theravada Buddhist conceptions held by some of his percussionist interlocutors-including the concept of the "notself" in karmic relation to all other beings-as one such ontology. I note that Western conceptions of the self that stress its temporal unfolding and immersion in the world, as opposed to a "stable, closed self (8)," are not uncommon in musical scholarship. Phenomenology's influence is widespread across the music disciplines, and there is a less-widespread but highly welcome influence of American Pragmatism through the presence of linguistic and semiotic anthropology in ethnomusicology. Sykes's particular ontologically relational methodology might have been augmented with relation to these literatures on selfhood, but, then again, The Musical Gift is already massive.

In the manner of classic critiques of the liberal public-private distinction (Pateman 1988, Gal 2001, Warner 2002), chapter one argues that British colonial politics and postcolonial ethnicized nation-building created artificial divisions between Sri Lanka's peoples, between the market and individual expression, and between "nature" and "culture," all of which were crossed by processes of musical giving. Sykes conceives of musical giving as a practical "technology of care" that produces values for others in the hope of conferring enduring relations, with any benefits for the self accrued through these relations. He expressly contrasts this form of giving to commodity consumption (15): he contrasts giving's pragmatic and technical nature to the mere "symbols" of commodity consumption and the identities produced by it, citing Talal Asad to draw the distinction between "symbol" and "practice" (16). If we follow this citation, we see that Asad actually claims that symbols are bound up in and acquire their potency through practices (Asad 1993, 17-18), which renders this particular distinction untenable, but Sykes's pragmatic thrust is a vitally productive part of the book. 


\section{Current Musicology}

Sykes describes the musical and sonic practice of Berava, Sinhalese Buddhist drummers with whom he studied and performed, as a practice of pragmatic giving and not an expression of communal subjectivity. To Sykes, such supposedly communal expressions are the necessary fate of music in conditions of political liberalism, wherein artistic practices are held to express identity and subjectivity, separate from the economic realm's impersonal relations of exchange mediated by the money-form (17). Sykes views the opposition between fluid material circulation and the ostensibly unified self s subjective expression as "liberal aesthetics," the critique of which is at the heart of this text. Berava sonic practices are conducted for healing purposes, but due to the postcolonial perdurance of colonial-era ideologies of "authenticity" and lowland Sri Lanka's extensive history with foreign powers, Berava sonic gifts are often devalued by political elites in comparison to "more-traditional" forms of expression from highland Kandy, and Kandyan practitioners frequently acquire institutional jobs at Berava expense (34-5). Yet it is precisely Berava sonic relations with "outsiders"-including the historical Tamil cultural influence they incorporate-that support Sykes's efforts to focus musical scholarship on interrelation between ostensibly bounded communities.

Chapter two extends this Berava sonic relationality from interactions between human communities to interactions with the nonhuman. In the process, Sykes offers an extensive historical organology of Sinhalese drumming that also addresses different forms of spiritual encounter, and traces both historical changes and changes across the island's space. Especially valuable here is an emic reworking of extant analyses of Berava drumming derived from Western conceptions of musical "experience" (79-80). Sykes's examination of changes in Berava drumming include spatialized and hierarchized changes in contemporary assignations of exchange-value to ritual experts' sonic encounters with spirits.

In parallel to chapter two, chapter three offers a lengthy geographical history of Tamil instruments, rituals, art songs, and forms of dramatic performance on the island, which also breach divisions between communities and the spiritual realm. Like Sinhalese religio-artistic practices, their audiences and practitioners assign them varying degrees of "authenticity" across time and space (113-4). Sri Lankan Tamil ties to South India and comparatively independent cultural practices are discussed in depth, including changing conceptions of caste and their effects on musical production (102-3), and the effects on music caused by migration and other movement due to the Civil War (108-110). Chapter 4 looks at some of the aftereffects of the War, including post-

War governmental emphasis on the classical or medieval character of Tamil 
music in order to obscure the relationality of Sinhalese and Tamil musics in the present day (157-9). In pursuit of this obscured relationality, Sykes provides concise histories of Sri Lanka's other major sociological fractions and outlines shared musical histories and practices among them. This includes an ethnicized Muslim population, whose musical activities include connections to transnational Sufi devotional practices, and equally transnational connections through conflict over the place of music in Islam with Sri Lankan mullahs of "Wahhabi" leanings (120-1) (note that in many contexts the use of this term is offensive to the conservative Muslims to whom it is applied-it indexes a specific school of Islamic jurisprudence tied to Saudi Arabia's government, which is separate from the practices of many South Asian Muslims-but perhaps it was not so to Sykes's interlocutors). Musics of Christian, African-descended, and Burgher populations whose arrival stemmed from Dutch and Portuguese colonization and trade are also discussed. The musical practices of all of the above, as well as Sri Lankan Tamil and Sinhalese drumming practices, are shown to unsettle what Sykes dubs the "Cartography of Culture Zones": the reductive spatialization in scholarship of Sri Lanka's various populations that served to artificially draw distinctions between peoples and musical practices who were far more interrelated than described in extant histories (136-9, 156-8).

Chapter 5 describes Sri Lanka's Civil War, the 2004 tsunami, the effects of both on musicians, and attempts to return to more livable conditions and a less fragmented polity afterwards. Musical efforts towards reconciliation have been cautiously initiated but are often stymied by new iterations of conflicts marked by nationalist linguistic ideologies and the specter of violent coercion, including debates over whether the Sri Lankan national anthem must be sung in Sinhala or Tamil. Sykes ascribes the failure of many of these efforts towards reconciliation - often NGO-led-to the lasting power of the music and identity episteme, which renews the very social boundaries these efforts seek to overcome. The ethnographic anecdotes in this chapter are affecting and impress upon the reader both the high stakes under discussion and the validity of many of Sykes's desired interventions.

Chapter 6 discusses how colonial discursive production of space shaped Sinhalese musical discourse. Much of this discourse stems from the kind of environmental determinisms that shaped global colonial administration and that persist to this day in popular rhetoric and histories (211-5, consider Jared Diamond's continued popularity). Sykes describes Sinhalese retroactive constructions of indigeneity as a reaction to these colonial logics, especially those that stress Sinhalese musical "degeneration" to emphasize social distance 


\section{Current Musicology}

between them and Sri Lankan Tamils (218-220). Sri Lanka's much-discussed post-Independence broadcasts of Indian film songs (as these popular songs were mostly banned from All-India Radio at the time) in turn instantiate postcolonial anxieties about Sinhala musical "degeneration" due to Indian cultural taint (2213). That ethnic isolationism was produced by colonial logics and yet persists after the end of the colony is one of history's cruel ironies, and Sykes productively outlines both the history of this isolationism, its dependence on the "identity episteme" and how such an episteme might be redressed.

An argument of such scope and complexity will necessarily contain a lot of moving parts, and that some of these parts are in contradiction with one another does not reflect badly upon the author. It is instead a testament to Sykes's care as a scholar that the book presents a thoroughgoing and coherent intellectual project, despite certain contradictions between some of the many conceptual lineages upon which he draws. These internal contradictions are not faults per se but they are worth looking at, as they contain different implications for his political and theoretical prescriptions. Sykes's recourse to the ontological turn includes a conflation of the stances of Viveiros de Castro, Philippe Descola, their many followers (on some significant distinctions between the aforementioned, see Turner 2009), and Elizabeth Povinelli (Sykes 2018, 12, 12n. 16). This makes for strange political bedfellows: Viveiros de Castro is proud of his success in achieving Brazilian state recognition for specific indigenous communities, and many anthropologists influenced by him point to the work of making claims on the state through establishing legally legible communities marked by ontological difference. On the other hand, Povinelli questions the politics of recognition and liberal notions of community identity entirely, pointing to these conceptions' destructive and directly extractive effects on Australian indigenous people (Povinelli 2002). Povinelli also critiques the ontological turn's political implications as an insufficient "multicultural social constructionism" (Povinelli 2014). I note that Sykes's oft-repeated call to abjure political liberalism and its historical effects, which is among the book's primary goals, would perhaps place him firmly in the camp of Povinelli. Indeed, Sykes quotes Povinelli at comparative length to describe the subsumption of musical gifts into "cultural" productions legible within liberal legal frameworks (18-19).

Furthermore, some anthropologists assert that the political projects of the ontological turn have not just played into the liberal politics of contemporary nation-states, but directly facilitated the very forms of genocide based on ascriptive identity that The Musical Gift is written against (Bessire and Bond 2014, which Sykes cites positively [Sykes 2018, 49-50, Sykes 2020], Bessire 2014). 
Moreover, much of the body of thought Sykes draws on for his critique of liberal aesthetics (Sykes 2018, 16-7), such as South Asian historians Ritu Birla and Andrew Sartori, view the ontology of commodified labor as pervasive, internalized, and rendered "vernacular" in the societies where it took root (Birla 2009, Sartori 2008, 2014). As this includes Sri Lanka it would have affected Berava ontologies as well, which makes Sri Lankan ontological difference seem perhaps less than politically efficacious. The respective conceptual bases of Sykes's ontological prescription and much of the remainder of his political critique are thus at odds.

Also of note is that Sykes's conception of gifting, which he describes as modeled on Sri Lankan practice (6), is sui generis-it differs in several important respects from many of economic anthropology's various contemporary and historic consensuses on the gift. He instead eclectically draws from popular writers conversant with but on the periphery of economic anthropology, such as Genevieve Vaughan (53-4) and Lewis Hyde $(47,49)$. Sykes's ideal typical practice of "musical giving" is a form of caring social interdependence whose spirit is very much unlike forms of agonistic prestation, such as the canonical anthropological depictions of potlatch and moka (15-17). When Sykes invokes the potlatch of the Pacific Northwest's First Nations he idiosyncratically analogizes it as a form of musical hoarding, not gifting, destructive of both the gift and the social bonds within the gift (159-161). Mauss claims the opposite, as do most economic anthropologists in the century after him. Nor does the social interdependence of Sykes's "musical giving" apply to forms of caring mutuality for some at others' expense-something fundamental to post-Mauss conceptions of the gift's perdurance in commodity relationships and fundamental to, say, kinship prestations across South Asian media industries and boardrooms.

Sykes's valuable insistence on the continual semiotic reinscription of the material world - such that musical texts and instruments produce different kinds of meaning in different regimes of value across social boundaries - both emphasizes the pragmatic wielding of (musical) objects and disavows notions of identity derived from the object wielded as "fetishism" (46-7). Though Sykes's emphasis on semiotic reinscription provides a much-appreciated corrective to some of the early applications of actor-network theory in musicology and ethnomusicology, this is exactly the opposite of one of the common takeaways from Mauss's essay on The Gift: that personhood is intimately bound up in objects in and out of exchange (Parry 1986, 456-7). This raises questions of how Sykes differentiates the pure intentions of his gifts from the many comparatively 


\section{Current Musicology}

"impure" gifting practices in the world, and at what point Sykes's humannonhuman relationality is distinct from material "fetishism."

Sykes's repeated distinction between "gift" as practical and "commodity" as "symbolic" of identity is also sui generis (16-7, 208-9). Note that large swathes of the ethnographic literature on contemporary musics and invocations of identity describe the many eminently practical means, however problematic, to which identity has been put. An attendant question, then, is whether it is only liberal individualism that necessarily produces the politics of individual and sectarian identity that Sykes so trenchantly critiques (56-9), or whether identity's rise stems from more specific entities that cannot (only) be found in the persistent colonial influence of seventeenth and eighteenth-century English political and economic theory. There is much documented evidence of this ethnographic specificity.

For example, Sykes engages in extensive macroscale theorizing about capital (including the very general assertion that "in capitalism, music becomes less alienable" (52-3)). He extrapolates from today's historically low wages for music in order to posit that capitalist social relations produce "the perception of music's worthlessness as labor except as an expression of the self (artist/community or consumer)" (ibid.). It is, however, likely that those low wages come from specific projects with specific class actors in specific locations, not (just) the commodity form as a whole, and thus a greater degree of ethnographic specificity may be warranted. Yet the historically specific role of liberal individualism, or of the process of commodification, in the production of a commodified Sri Lankan identity is not discussed here beyond the provocative drawing of conceptual parallels. There is a large literature on the commodification of extant categories of ascriptive identity, much of which posits such commodification as directly indexed to specific political economic conditions, and not (only) to "capitalist logics" or "neoliberalism" writ large. Categories of ascriptive identity can be fundamental to capitalist social relations - legally enshrined ethnic inequality, for one obvious instance-without being directly commodified. And conversely, the direct commodification of signs of ethnicity, as opposed to capitalizing in the labor market upon the lowered exchange-value of the labor of those who ostensibly bear ethnicity, is a historically specific project whose contemporary resurgence has been indexed by many scholars to historically specific events. These include the decline of Fordism (Shoshan 2016), Indian national attempts to court investment in the wake of increased global financialization (Kaur 2020), state spatial restructuring produced by rollback of Nehruvian reforms (Kennedy 2013), Cuban state 
attempts to produce national narratives and musical history in light of economic vulnerability (Wirtz 2014), and so on. The move from macro-scale generalization to political-economic meso-scale would be a productive site for future scholarship in Sri Lanka that builds on Sykes's excellent foundation.

This is an important publication whose political ambition and conceptual scope make it worthwhile reading for scholars, students, and laypersons across disciplines, but it is especially important for those involved in ethnomusicology. Though one may not agree with every one of its specific propositions-as many of the literatures upon which Sykes draws are in conflict, some readers may be forced to pick and choose according to their tastes-at the very least its inroads into critical geography tread highly productive ethnomusicological terra nulla. Its critical interventions-whether through its critique of liberal aesthetics, its thorough examination of the "music and identity episteme," or the brief address of several ethnomusicological theoretical trends that have carried water for said episteme-are vital for the discipline. If music scholarship is to maintain a critical backbone, and if it is to have any purchase on genocide and the construction of ethnicity and ascriptive identity in contemporary life, then it must contend with the questions raised by The Musical Gift, and perhaps repay them in kind.

References

Bessire, Lucas. 2014. Behold the Black Caiman: A Chronicle of Ayoreo Life. Chicago: The University of Chicago Press.

Bessire, Lucas, and David Bond. 2014. "Ontological Anthropology and the Deferral of Critique.” American Ethnologist 41, no. 3 (2014): 440-56. https://doi.org/10.1111/amet.12083.

Birla, Ritu. 2009. Stages of Capital: Law, Culture, and Market Governance in Late Colonial India. Durham, NC: Duke University Press.

Dirksen, Rebecca. 2019. "Haiti's Drums and Trees: Facing Loss of the Sacred." Ethnomusicology 63 (1): 43. https://doi.org/10.5406/ethnomusicology.63.1.0043.

Gal, Susan. 2002. "A Semiotics of the Public/Private Distinction." Differences: A Journal of Feminist Cultural Studies 13 (1): 77-95.

Kaur, Ravinder. 2020. Brand New Nation: India in the Global Economy. Redwood City: Stanford University Press.

Kennedy, Lorraine. 2013. The Politics of Economic Restructuring in India: Economic Governance and State Spatial Rescaling. New York: Routledge.

Mauss, Marcel. 2016. The Gift. Translated by Jane I. Guyer. Chicago: HAU Books. Mori, Bernd Brabec de, and Anthony Seeger. 2013 "Introduction: Considering Music, Humans, and Non-Humans.” Ethnomusicology Forum 22, no. 3 (December 1): 26986. https://doi.org/10.1080/17411912.2013.844527. 


\section{Current Musicology}

Parry, Jonathan. 1986. "The Gift, the Indian Gift and the 'Indian Gift."' Man 21, no. 3

(September). https://doi.org/10.2307/2803096.

Pateman, Carole. 1988. The Sexual Contract. Stanford, CA: Stanford University Press.

Povinelli, Elizabeth A. 2014. "'Geontologies of the Otherwise': Theorizing the

Contemporary." Society for Cultural Anthropology, January 13,

https://culanth.org/fieldsights/geontologies-of-the-otherwise.

2002. The Cunning of Recognition: Indigenous Alterities and the Making of

Australian Multiculturalism. Durham, NC: Duke University Press.

Sartori, Andrew. 2008. Bengal in Global Concept History: Culturalism in the Age of Capital.

Chicago: University of Chicago Press.

2014. Liberalism in Empire: An Alternative History. Oakland, CA: University of California Press.

Schuiling, Floris. 2019. "Notation Cultures: Towards an Ethnomusicology of Notation."

Journal of the Royal Musical Association 144 (2): 429-458.

doi:10.1080/02690403.2019.1651508.

Shoshan, Nitzan. 2016. The Management of Hate: Nation, Affect, and the Governance of

Right-Wing Extremism in Germany. Princeton: Princeton University Press.

Sykes, Jim. 2020. “The Anthropocene and Music Studies." Ethnomusicology Review 22 (1): 18. 2018. The Musical Gift: Sonic Generosity in Post-War Sri Lanka. Oxford: Oxford University Press. https://doi.org/10.1093/oso/9780190912024.001.0001.

Turner, Terry. 2009. "The Crisis of Late Structuralism. Perspectivism and Animism:

Rethinking Culture, Nature, Spirit, and Bodiliness." Tipití: Journal of the Society for the Anthropology of Lowland South America 7, no. 1 (June 1).

https://digitalcommons.trinity.edu/tipiti/vol7/iss1/1.

Warner, Michael. 2002. "Publics and Counterpublics." Quarterly Journal of Speech 88 (4):

413-25. https://doi.org/10.1080/00335630209384388.

Wirtz, Kristina. 2014. Performing Afro-Cuba: Image, Voice, Spectacle in the Making of Race and History. Chicago: University of Chicago Press. 